\title{
Evaluation of antimicrobial edible coatings from a whey protein isolate base to improve the shelf life of cheese
}

\author{
Ó. L. Ramos, ${ }^{\star} \dagger$ J. O. Pereira, ${ }^{\star}$ S. I. Silva, ${ }^{\star}$ J. C. Fernandes, ${ }^{*}$ M. I. Franco, ${ }^{\star}$ J. A. Lopes-da-Silva, $\ddagger$ \\ M. E. Pintado, ${ }^{*}$ and F. X. Malcata $\S^{1}$ \\ ${ }^{*} \mathrm{CBQF} /$ Escola Superior de Biotecnologia, Universidade Católica Portuguesa, Rua Dr. António Bernardino de Almeida, P-4200-072 Porto, Portugal \\ †Instituto de Tecnologia Química e Biológica, Universidade Nova de Lisboa, Avenida da República, P-2780-157 Oeiras, Portugal \\ ¥QOPNA, Department of Chemistry, University of Aveiro, P-3810-193 Aveiro, Portugal \\ $\S$ Department of Chemical Engineering, University of Porto, Rua Dr. Roberto Frias, P-4200-465 Porto, Portugal
}

\begin{abstract}
The objective of this work was to evaluate the effectiveness of antimicrobial edible coatings to wrap cheeses, throughout $60 \mathrm{~d}$ of storage, as an alternative to commercial nonedible coatings. Coatings were prepared using whey protein isolate, glycerol, guar gum, sunflower oil, and Tween 20 as a base matrix, together with several combinations of antimicrobial compounds - natamycin and lactic acid, natamycin and chitooligosaccharides (COS), and natamycin, lactic acid, and COS. Application of coating on cheese decreased water loss $(\sim 10 \%$, wt/wt), hardness, and color change; however, salt and fat contents were not significantly affected. Moreover, the antimicrobial edible coatings did not permit growth of pathogenic or contaminant microorganisms, while allowing regular growth of lactic acid bacteria throughout storage. Commercial nonedible coatings inhibited only yeasts and molds. The antimicrobial edible coating containing natamycin and lactic acid was the best in sensory terms. Because these antimicrobial coatings are manufactured from food-grade materials, they can be consumed as an integral part of cheese, which represents a competitive advantage over nonedible coatings.
\end{abstract} Key words: edible coating, whey protein isolate, antimicrobial compound, cheese shelf life

\section{INTRODUCTION}

Cheese encompasses the most diverse group of dairy products, with different formats, textures, aromas, and flavors being the result of specific manufacture and ripening protocols. The complex composition of cheese and the environmental conditions prevailing throughout handling and storage often promote uncontrolled and extensive fungal and bacterial development on its surface, which considerably reduces its quality, causes

Received February 28, 2012.

Accepted June 28, 2012.

${ }^{1}$ Corresponding author: fmalcata@itqb.unl.pt economical losses to the industry, and may even lead to health problems on the consumer side (de Oliveira et al., 2007). In unpackaged cheese, water loss depends on the chemical properties of the cheese itself and on the storage conditions. Although the shelf life of cheese can be extended via lower rates of water loss, provision of a coating is a more effective strategy toward this endeavor (Pantaleão et al., 2007).

Commercial coatings made of nonedible polymers, such as polyvinyl acetate (PVA), have been in use for a long time, and are aimed at moisture regulation and protection against microbial contamination (Reps et al., 2002). However, the food and packaging industries, as well as consumers, demand natural and biodegradable food packaging materials that are able to extend shelf life without chemical preservatives (Cerqueira et al., 2009). Whey protein films and coatings have received a special attention because, in addition to being edible and biodegradable, they convey an upgrade of whey as a major by-product of the cheese industry. Whey protein isolates (WPI) represent a pure form of whey protein products (Mulvihill and Ennis, 2003); they have interesting mechanical features and possess oxygen-barrier properties comparable to those of the best synthetic polymer-based films, as reviewed elsewhere (Perez-Gago and Krochta, 2002; Khwaldia et al., 2004; Ramos et al., 2012a). Moreover, WPI can serve as carriers of various additives such as antimicrobial compounds (Campos et al., 2011); this enables extension of shelf life and enhancement of safety of the packaged food by maintaining high concentrations of the active substance on the food surface for a longer period (Ponce et al., 2008). In addition, they can provide good and selective barriers to moisture transfer, oxygen uptake, lipid oxidation, and loss of volatile aromas and flavors, as well as a better visual aspect, thus hampering weight loss reduction and respiratory rate (Kester and Fennema, 1986). However, application of edible coatings to extend the shelf life of cheese has seldom been explored. Kampf and Nussinovitch (2000) used k-carrageenan, alginate, and gellan coatings, whereas Cerqueira et al. 
(2010) applied galactomannan and chitosan coatings to semihard cheeses; both groups reported a reduced weight loss of the coated cheeses. Duan et al. (2007) and Fajardo et al. (2010) showed, in turn, that chitosan coatings incorporated with lysozyme or natamycin, respectively, could be successfully applied to Mozzarella and Saloio cheese packages to control postprocessing contamination, thus improving their microbial safety.

To the best of our knowledge, no work has been developed to date pertaining to use of a WPI coating as carrier of lactic acid, natamycin, or chitooligosaccharides (COS), or combinations thereof, to prevent microbial growth on cheese surfaces. Therefore, the aim of this study was to assess the effectiveness of antimicrobial edible coatings made from WPI $(10 \%, \mathrm{wt} / \mathrm{wt})$, glycerol $(5 \%, \mathrm{wt} / \mathrm{wt})$, guar gum $(0.7 \%$, wt $/ \mathrm{wt})$, sunflower oil $(10 \%$, wt/wt), and Tween $20(0.2 \%$, wt/wt) as a base matrix, with the incorporation of several combinations of antimicrobial compounds: natamycin $(0.25 \mathrm{~g} / \mathrm{L})$ and lactic acid $(6 \mathrm{~g} / \mathrm{L})$, natamycin $(0.25 \mathrm{~g} / \mathrm{L})$ and $\operatorname{COS}(20$ $\mathrm{g} / \mathrm{L})$, and natamycin $(0.25 \mathrm{~g} / \mathrm{L})$, lactic acid $(6 \mathrm{~g} / \mathrm{L})$, and $\operatorname{COS}(20 \mathrm{~g} / \mathrm{L})$, to wrap cheeses as an alternative to commercial nonedible coatings. These formulations were selected based on previous studies of technical feasibility (Ramos et al., 2012c,d, 2013), coupled with efforts toward optimization (Ramos, 2011). Their effectiveness was evaluated by periodically measuring physicochemical, microbiological, and sensory features throughout $60 \mathrm{~d}$ of storage, and comparing the data with those obtained from cheeses with a commercial coating (made of PVA) and uncoated cheeses. Regional Saloio cheese was chosen as the model because it is one of the most widely consumed in Portugal and because current manufacture practices promote development of relevant spoilage or pathogenic microflora on its surface that unfavorably affect flavor. Furthermore, the commercial solution found for this problem has so far relied on application of a PVA coating containing an antifungal agent (natamycin) onto its surface; hence, our edible coating was tested as a realistic alternative for actual shelf-life extension.

\section{MATERIALS AND METHODS}

\section{Materials}

Whey protein isolate was obtained from Armor Proteines (Saint Brice en Coglés, France) and characterized previously (Ramos et al., 2012b), according to the following composition data (dry-weight basis): $92.0 \%$ (wt/wt) protein, $1.0 \%$ (wt/wt) lipid, $1.0 \%$ (wt/wt) lactose, $2.0 \%$ (wt/wt) ash and 3.0\% (wt/wt) moisture, as well as $389.1 \mathrm{mg}$ of calcium, $100.1 \mathrm{mg}$ of sodium, and $31.1 \mathrm{mg}$ of potassium per $100 \mathrm{~g}$. Glycerol $(99 \%$ purity) was supplied by Panreac (Barcelona, Spain), and peptone (P7750) was obtained from Sigma (St. Louis MO). A fraction of COS with a nominal molecular weight $<3 \mathrm{kDa}$ was purchased from Nicechem (Shanghai, China) and used as received. The COS had been obtained via enzymatic hydrolysis of chitosan from crab shells; the deacetylation degree ranged from 80 to $85 \%$ (as per supplier). Lactic (98\% purity, L1750) and propionic (99\% purity, P1386) acids, as well as Tween 20 (P1379) and guar gum (G4129) were obtained from Sigma; natamycin (50\% purity) was provided by Mapril (Maia, Portugal); sunflower oil was obtained from Sovena (Barreiro, Portugal); ultrapure water (resistivity: $18.2 \mathrm{M} \Omega \mathrm{cm}$ ) was obtained with a Milli-Q Ultrapure water purification system (Millipore, Bedford, MA); and the commercial coating composed of PVA (as base material) and $\sim 2.5 \mathrm{~g} / \mathrm{L}$ natamycin (as active component) was provided by Mapril. All other chemicals were reagent-grade or better, and were used without further purification.

\section{Cheese}

The cheese under study is a cylindrical, strawcolored, semihard cheese and was kindly supplied by Queijo Saloio (Torres Vedras, Portugal), without any previous treatment (i.e., without ripening or coating), 2 d after manufacture. Regional Saloio cheese is a full-fat cheese produced from a mixture of pasteurized caprine, bovine, and ovine milks, which is sold commercially with a PVA coating containing an antifungal agent (usually natamycin). After coating, the cheeses (weighing $\sim 250 \mathrm{~g}$ per unit) are typically submitted to a short ripening period $(\sim 15 \mathrm{~d})$ at low temperature $\left(\sim 10^{\circ} \mathrm{C}\right)$ and require refrigeration in both the retail and home settings before consumption. The typical composition of Saloio is as follows: moisture, $46 \%$ (wt/wt); fat, $25 \%$ (wt/wt); protein, $18.4 \%$ (wt/wt); total ash, $3.58 \%$ (wt/ wt); chlorides, $1.54 \%$ (wt/wt); $\mathrm{pH} 4.8$; and total acidity, $1.40 \mathrm{~g}$ of lactic acid/100 g of cheese (Pantaleão et al., 2007).

\section{Antimicrobial Solution Preparation}

The stock solutions of COS, lactic acid, and natamycin were prepared following the procedure described previously (Ramos et al., 2012d). The antimicrobial solutions were obtained by combining equal ratios of each compound: solution $1=60 \mathrm{~g} / \mathrm{L}$ lactic acid and $2.5 \mathrm{~g} / \mathrm{L}$ natamycin $(1: 1, \mathrm{vol} / \mathrm{vol})$, solution $2=200 \mathrm{~g} / \mathrm{L}$ COS and $2.5 \mathrm{~g} / \mathrm{L}$ natamycin $(1: 1, \mathrm{vol} / \mathrm{vol})$, and solution $3=$ $60 \mathrm{~g} / \mathrm{L}$ lactic acid, $200 \mathrm{~g} / \mathrm{L}$ COS, and $2.5 \mathrm{~g} / \mathrm{L}$ natamy$\operatorname{cin}(1: 1: 1, \mathrm{vol} / \mathrm{vol} / \mathrm{vol})$. The decision to incorporate the aforementioned antimicrobial solutions was a result of 
the good performance exhibited by lactic acid $(6 \mathrm{~g} / \mathrm{L})$ and $\operatorname{COS}(20 \mathrm{~g} / \mathrm{L})$ against gram-positive and gramnegative bacteria, respectively, when incorporated into a coating and edible film matrix base (Ramos et al., 2012c,d), respectively, and by natamycin against yeasts when incorporated in an edible film matrix base (Ramos et al., 2012d).

\section{Antimicrobial Coating Preparation}

Coating-forming solutions were prepared by slowly dissolving $10 \%$ (wt/wt) WPI powder in deionized water, following the procedure reported by Perez-Gago and Krochta (2002). Glycerol was added (5\%, wt/wt) as a plasticizer, based on recommendations from previous studies (Ramos et al., 2013); the resulting solutions were magnetically stirred for approximately $2 \mathrm{~h}$. Subsequently, solutions were heated for $20 \mathrm{~min}$ in a water bath at $80 \pm 2^{\circ} \mathrm{C}$ under continuous agitation. The solutions were cooled to $45^{\circ} \mathrm{C}$ over $1 \mathrm{~h}$ and $0.7 \%$ (wt/wt) guar gum was added at this temperature and stirred for approximately 20 min to ensure good dissolution; guar gum is a natural food thickener aimed at increasing viscosity (Skurtys et al., 2010). Then, 10\% (wt/wt) sunflower oil was incorporated to reduce the water vapor permeability of the coating matrix base, to minimize the dehydration that typically accompanies ripening of Saloio cheese (Pantaleão et al., 2007; Cerqueira et al., 2010), and to allow greater compatibility between edible coating and cheese surface polarities (Cerqueira et al., 2009). Tween 20 (0.2\%, wt/wt) was incorporated as a surfactant to overcome the tendency for phase separation between polymer mixtures of WPI and polysaccharide gums (Syrbe et al., 1995), and as an emulsifier to assist in essential oil dissolution via the hydrophilic and hydrophobic parts of that molecule (Ojagh et al., 2010). Both compounds were added under stirring for approximately $20 \mathrm{~min}$ at room temperature. The solutions were homogenized at 19,000 rpm for 4 min using an UltraTurrax T25 homogenizer (IKA Labortechnik, Staufen, Germany). The 3 antimicrobial solutions prepared previously $(10 \%$, wt/wt) were incorporated into the edible coating matrix to attain the minimum lethal concentration of each compound (i.e., $6 \mathrm{~g} / \mathrm{L}$ lactic acid, $20 \mathrm{~g} / \mathrm{L} \mathrm{COS}$, and $0.25 \mathrm{~g} / \mathrm{L}$ natamycin) as determined previously by Ramos et al. (2012d). Then, vacuum was applied for $30 \mathrm{~min}$ to remove dissolved air (Seydim and Sarikus, 2006). Finally, the solutions were adjusted to pH 7.0 using $0.1 \mathrm{~mol} / \mathrm{L} \mathrm{NaOH}$.

Incorporation of guar gum, sunflower oil, and Tween 20 in the edible coating matrix base at the aforementioned concentrations (i.e., $10 \%$ WPI with $5 \%$ glycerol, wt/wt) was based on the results of several physical and rheological tests carried out elsewhere (Ramos, 2011).
The tests confirmed that these concentrations were optimal to improve viscosity, hydrophobicity, and stability of the base matrix without significantly compromising its physical properties.

\section{Cheese Coating}

The antimicrobial edible coating solutions, as well as the commercial nonedible coating (positive control), were adjusted to $\mathrm{pH} 7.0$ (using $1 \mathrm{~mol} / \mathrm{L} \mathrm{NaOH}$ ) to guarantee that the coatings were devoid of any significant antimicrobial activity associated with $\mathrm{pH}$ itself; hence, any antimicrobial activity observed would be caused by the antimicrobial compounds included in the formulation. The coatings were applied directly on the surface of cheeses $2 \mathrm{~d}$ after manufacture (in the absence of any other type of protective coating added onto the cheese surface). Coatings were applied by dipping cheese samples for 2 min until all surfaces were covered, with the residual coating being allowed to drip off. Coating application was performed in an appropriate aseptic chamber. The cheeses were then left for $8 \mathrm{~h}$ at $12^{\circ} \mathrm{C}$ ( $85 \%$ relative humidity), in a temperature- and humidity-controlled room, turning them periodically (every $30 \mathrm{~min}$ or so) until the coating was essentially dry (based on visual inspection). Then, cheeses were stored for $60 \mathrm{~d}$ at $10^{\circ} \mathrm{C}$ and $85 \%$ relative humidity. The coated cheeses were compared with their uncoated (negative control) counterparts.

\section{Cheese Analyses}

Cheeses were assayed, in triplicate, on 1, 10, 20, 40, and $60 \mathrm{~d}$ after coating application, for physicochemical properties: moisture, fat, and salt contents; weight loss; $\mathrm{pH}$; water activity; texture; and color. Microbiological and sensory analyses were also performed.

Moisture, Fat, and Salt Contents. Moisture, fat, and salt contents were determined using Fourier transform infrared spectroscopy, in a LactoScope Advanced FTIR (Delta Instruments, Drachten, the Netherlands). Five readings were taken of each cheese sample.

Weight Loss. Cheese was individually weighed on an automatic electro-balance PM 1200 (Mettler, Columbus, $\mathrm{OH}$ ), with a precision of $\pm 0.001 \mathrm{~g}$, at the beginning and during the storage period; the relative weight loss, $\Delta W$, was calculated as

$$
\Delta W=\left(I_{w 0}-F_{w i}\right) / I_{w 0},
$$

where $I_{w 0}$ is the initial weight and $F_{w i}$ is the final weight at time $i$. Three readings of each cheese sample were produced.

$\boldsymbol{p H}$. The $\mathrm{pH}$ value was measured using a $\mathrm{pH}$ meter (Micro pH 2002, Crison, Barcelona, Spain), equipped 
with a probe for solids inserted directly into the cheese sample. Three readings of each cheese sample were taken.

Water Activity. The water activity $\left(\mathbf{a}_{\mathrm{w}}\right)$ of cheese samples was measured using a HygroLab 2 water activity indicator (Rotronic, Bassersdrof, Germany). Pieces of cheese $(\sim 20 \mathrm{~g})$ representing the bulk and surface of the cheese were placed on the sample holder of the $\mathrm{a}_{\mathrm{w}}$ device, and a sealed system was formed by placing the $\mathrm{a}_{\mathrm{w}}$ probe on top of the sample holder. When $\mathrm{a}_{\mathrm{w}}$ became constant (usually $<1 \mathrm{~h}$ ), its value was recorded. Calibration was achieved by comparison to 6 saturated solutions of known $\mathrm{a}_{\mathrm{w}}: \mathrm{LiCl}=0.114, \mathrm{MgCl}_{2}=0.329$, $\mathrm{K}_{2} \mathrm{CO}_{3}=0.443, \mathrm{Mg}\left(\mathrm{NO}_{3}\right)_{2}=0.536, \mathrm{NaBr}=0.653$ and $\mathrm{KCl}=0.821$. Four readings of each cheese sample were obtained.

Texture. The textural properties of cheese samples were evaluated using a texture analyzer (TA.XT Plus, Stable Micro Systems, Surrey, UK), with a 5-kg load cell and a 5-mm cylindrical plunger, at a constant penetration speed of $2 \mathrm{~mm} / \mathrm{min} ; 3$ penetrations were performed per cheese at distinct locations. This type of test permitted measurement of hardness, defined as the maximum peak force during compression (first bite). The software (Texture Expert for Windows v. 1.20, Stable Microsystems) converted the force deformation readings into hardness values.

Color. Cheese color was evaluated using a portable Chroma meter CR-400 (Minolta Chroma, Osaka, Japan). Changes in color of the cheese surface were measured using a CIELab color scale (where $L=$ lightness, $a=$ red-yellow color, and $b=$ blue-green color) under daylight ( $D_{65}$ illuminant). A standard white plate was used to calibrate the equipment, with color coordinates $L_{\text {standard }}=97.6, a_{\text {standard }}=0.01$, and $b_{\text {standard }}=1.60$. The total color difference $(\Delta E)$ was calculated as follows:

$$
\Delta E=\left[\left(L-L_{0}\right)^{2}+\left(a-a_{0}\right)^{2}+\left(b-b_{0}\right)^{2}\right]^{1 / 2},
$$

where $L_{0}, a_{0}$, and $b_{0}$ were the initial values $(1 \mathrm{~d}$ after coating application) obtained for cheese under each experimental condition, and $L, a, b$ were the values measured throughout the storage period. For each cheese sample, 4 readings were made on each side.

Microbiological Analyses. Microbiological development on the cheese surface was evaluated via enumeration of viable cells by $1,10,20,40$, and 60 $\mathrm{d}$ after application of coatings. A 20-g sample was removed aseptically from a standardized area of the cheese surface into a Stomacher (Seward, West Sussex, UK) bag and diluted to $1: 10$ (wt/vol) in sterile $1 \%$ (wt/vol) sodium citrate (Merck, Darmstadt, Germany) via blending in a Stomacher 400 Circulator (Seward) for $1.5 \mathrm{~min}$ at $260 \mathrm{rpm}$. Subsequently, decimal dilu- tions were prepared with $0.1 \%$ (wt/vol) peptone water (Sigma) and plated, in duplicate, on the corresponding media. Lactococcus spp. and Lactobacillus spp. were enumerated on M17 agar (Lab M, Bury, UK) and Rogosa agar (Biokar Diagnostics, Pantin, France), respectively, and incubated under anaerobic conditions (BBL Gas-Pack System, Becton Dickinson, Franklin Lakes, NJ) at $37^{\circ} \mathrm{C}$ for $72 \mathrm{~h}$. Total mesophilic aerobic bacteria were enumerated on plate count agar (Biokar Diagnostics), incubated aerobically at $30^{\circ} \mathrm{C}$ for $72 \mathrm{~h}$. Staphylococcus spp. were enumerated on Baird-Parker agar (Lab M), supplemented with egg yolk and tellurite emulsion (Biokar Diagnostics), as proposed by BairdParker (1969). Pseudomonas spp. were enumerated on Pseudomonas agar base (Lab M), adjusted to $\mathrm{pH} 5$ with acetic acid (Merck). Both Baird-Parker and Pseudomonas media were incubated aerobically at $37^{\circ} \mathrm{C}$ for 48 h. Enterobacteriaceae were counted on violet red bile glucose agar (Lab M), incubated aerobically at $37^{\circ} \mathrm{C}$ for $24 \mathrm{~h}$, whereas yeasts and molds were determined on rose bengal agar (Lab M), with $0.1 \mathrm{~g} / \mathrm{L}$ chloramphenicol (Fluka, Buchs, Switzerland), incubated aerobically at $25^{\circ} \mathrm{C}$ for $5 \mathrm{~d}$. For all samples and growth media, the surface plating technique described by Miles et al. (1938) was followed, except with violet red bile glucose agar, for which the pour-plate technique was used.

Sensory Analyses. Sensory evaluation was carried out in the sensory room of Centro de Biologia e Química Fina (CBQF) (Porto, Portugal), by a trained panel of 15 members (both sexes, ages ranging between 26 and 40 yr old), familiar with Portuguese regional cheeses. The panel had previously been screened and selected from among staff and students of CBQF; its membership was trained in evaluating this product for approximately $80 \mathrm{~h}$, thus meeting the recommendation by Meilgaard et al. (1999) of at least 50 to $100 \mathrm{~h}$ for effective and trustworthy sensory assessments. The sensory trials were intended to assess the influence of antimicrobial edible coatings on color, odor, hardness, and flavor of coated cheese, as well as to compare cheeses with antimicrobial edible coatings with cheese coated with commercial coating and uncoated cheese.

Cheese samples (in duplicate) were equilibrated at room temperature $\left(20 \pm 2^{\circ} \mathrm{C}\right)$ for $1 \mathrm{~h}$ before the sensory analysis sessions and were evaluated only upon previous confirmation of microbiological safety. For evaluation of cheese appearance, the whole cheese was first analyzed by the panel; then, it was cut into slices approximately $2 \mathrm{~cm}$ thick that were placed on individual Petri plastic dishes. The dishes were coded using random 3-digit codes and presented in random order to panelists under white fluorescent light. The panelists used unsalted crackers and water to cleanse their palates between samples. 
A 5-point scale was used by the panelists to evaluate ring color $(1=$ imperceptible and $5=$ intense $)$, odor $(1$ $=$ imperceptible and $5=$ intense $)$, hardness $(1=$ very soft and $5=$ very hard $)$, flavor $(1=$ imperceptible and $5=$ intense), and overall acceptability ( 1 to $2=$ not accepted, $3=$ accepted and 4 to $5=$ most accepted). The sensory cards included an "Observations" section, in which the panelists were asked to indicate any defects noticed or any descriptors considered useful to better define the coating attributes.

\section{Statistical Analyses}

Analysis of variance was performed to assess the differences between the physicochemical, microbiological, and sensory properties of the cheeses coated with the antimicrobial edible coating solutions or commercial coating compared with uncoated cheese on $0,10,20$, 40 and $60 \mathrm{~d}$ of storage. The SPSS software (v. 17.0, SPSS Inc., Chicago, IL) was used for analysis. Duncan's multiple range test was applied and differences were considered significant at $P<0.05$.

\section{RESULTS AND DISCUSSION}

\section{Appearance of Coated Cheese}

The appearance of cheeses coated with the edible coating matrix, incorporated with any of the 3 antimicrobial solutions, was compared with that of cheese with commercial coating (positive control) and uncoated cheese (negative control) at $0 \mathrm{~d}$ of storage (Figure 1).

Cheese coated with solution 1 exhibited a similar appearance to its uncoated counterpart, although the coated cheese was slightly clearer. However, cheeses coated with solution 2 or 3 exhibited a yellow-brownish color; this could be attributed to the natural color of COS, which, in solution, is yellow-brownish. On the other hand, cheese with commercial coating was brighter than cheese bearing other coatings (Figure 1).
Moreover, the appearance of the various sides of the cheese was uniform, which was likely a result of efficient application of coatings following the procedure reported herein (i.e., dipping for $2 \mathrm{~min}$ ).

The antimicrobial edible coating solutions applied on the cheese surface dried in a similar time interval as the commercial coating $(\sim 8 \mathrm{~h})$ and showed similar adhesion to the cheese surface (based on visual inspection). A relatively high level of addition of glycerol (5\%, vol/vol) is required for good plasticizing, as well as appropriate permeabilities and thermal, mechanical, and optical properties (Ramos et al., 2013). However, scale-up of our product will not be a problem because glycerol is a feedstock available in increasingly larger amounts worldwide as a by-product of biodiesel manufacture.

\section{Physicochemical Profile}

Physicochemical analyses were performed by comparing cheeses coated with the edible coating solutions with commercial coating and uncoated counterparts. Physicochemical properties of cheese were assayed at 0 , 10, 20, 40, and $60 \mathrm{~d}$ of storage and are shown in Figure 2 .

Our analyses provided information on how water loss throughout $60 \mathrm{~d}$ of storage was affected by the presence of coating and the type of coating. Figure 2a shows an increase in weight loss for all cheeses throughout storage time; this increase was statistically greater $(P$ $<0.05)$ in the first $20 \mathrm{~d}$ for all cheeses and for the uncoated cheese compared with the coated cheeses. Significant differences $(P>0.05)$ were not found among the antimicrobial edible coating solutions and between those and the commercial coating.

In terms of moisture content, values decreased significantly $(P<0.05)$ over the first $20 \mathrm{~d}$ of storage. Coated cheeses displayed moisture losses by $60 \mathrm{~d}$ ranging from 17 to $19 \%$ (wt/wt), and uncoated cheese displayed moisture losses of approximately $27 \%$ (wt/wt; Figure $2 \mathrm{~b})$. Again, significantly higher $(P<0.05)$ values were

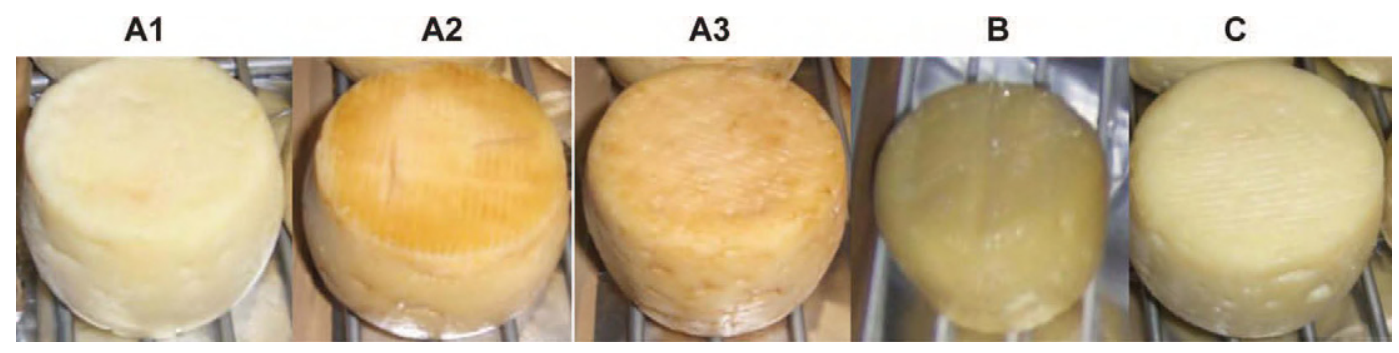

Figure 1. Appearance of cheeses (approximately $250 \mathrm{~g}$ each) coated with antimicrobial edible coatings incorporated with (A1) solution 1 (6 $\mathrm{g} / \mathrm{L}$ lactic acid and $0.25 \mathrm{~g} / \mathrm{L}$ natamycin), (A2) solution $2[20 \mathrm{~g} / \mathrm{L}$ chitooligosaccharides (COS) and $0.25 \mathrm{~g} / \mathrm{L}$ natamycin], or (A3) solution 3 (6 $\mathrm{g} / \mathrm{L}$ lactic acid, $20 \mathrm{~g} / \mathrm{L} \mathrm{COS}$, and $0.25 \mathrm{~g} / \mathrm{L}$ natamycin), compared with cheese coated with commercial coating (B; positive control) and uncoated cheese $(\mathrm{C}$; negative control) at $0 \mathrm{~d}$ of storage. Color version available in online PDF. 
a)

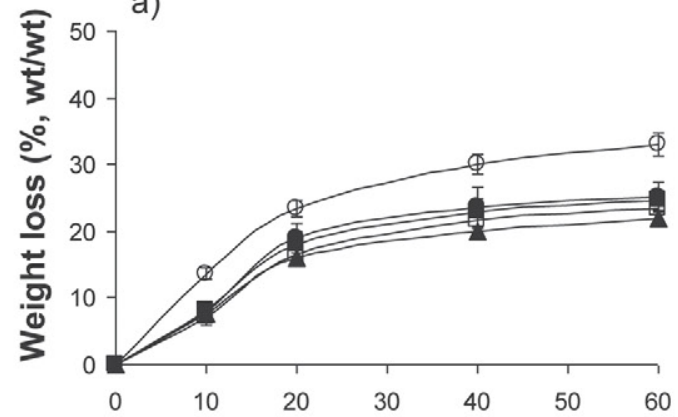

c)

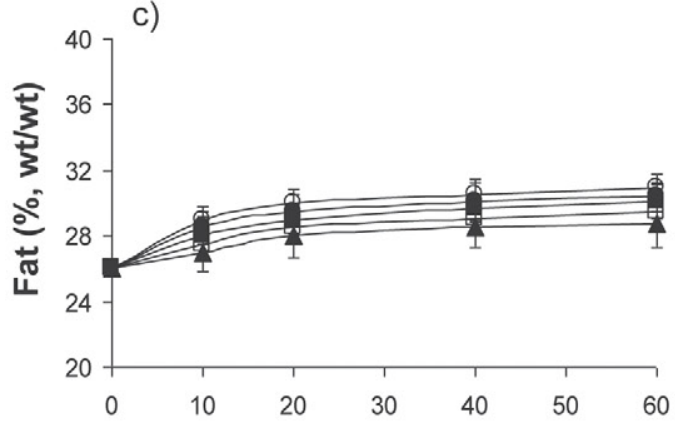

e)

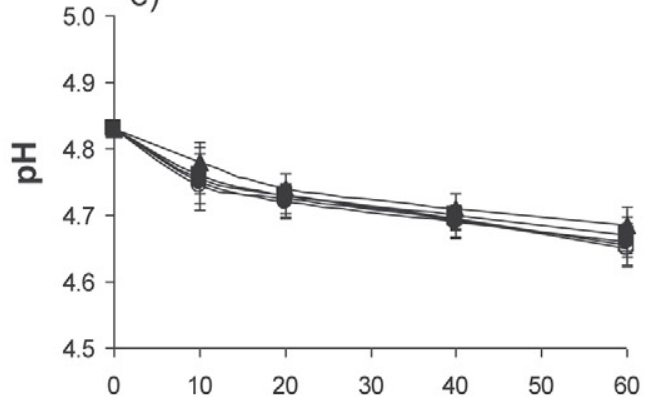

g)

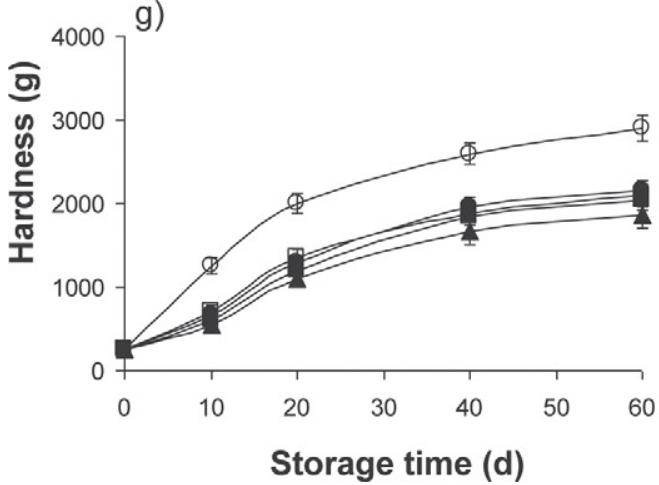

b)

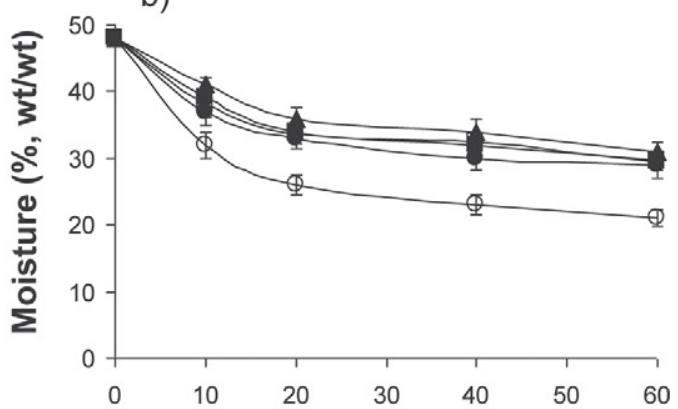

d)
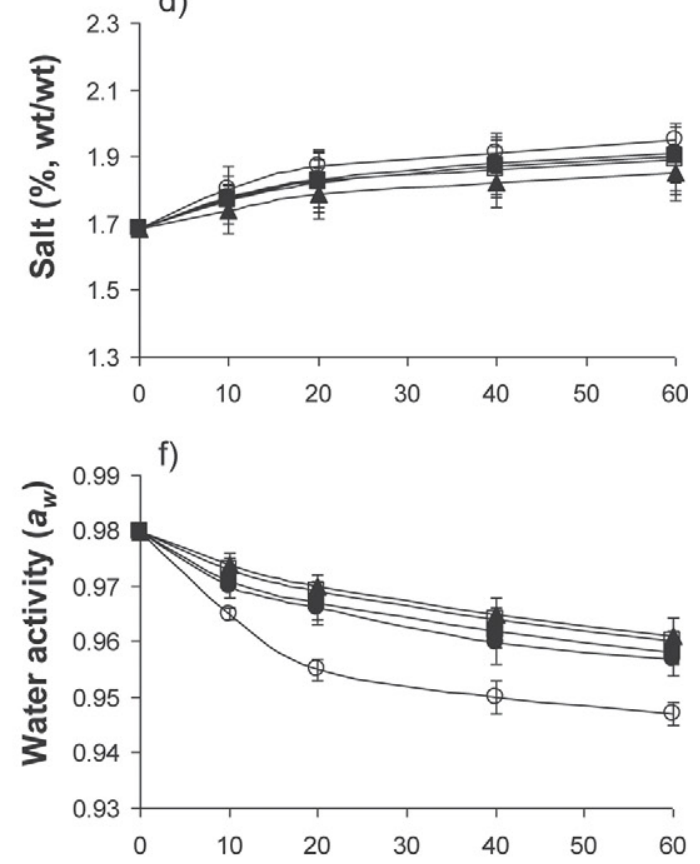

h)

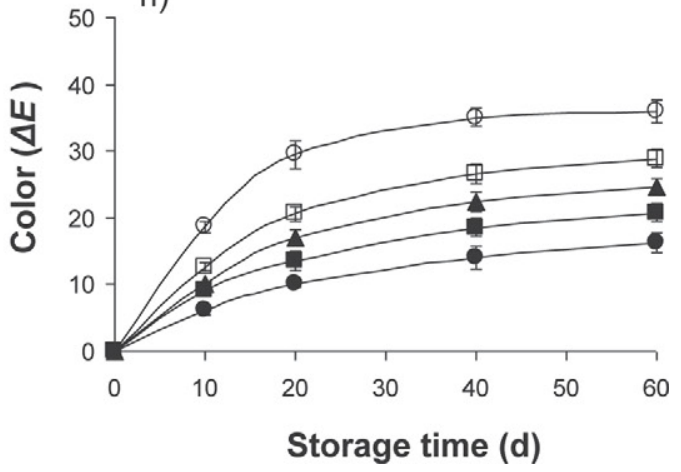

Figure 2. Values (means $\pm \mathrm{SD}$ ) of (a) weight loss, (b) moisture, (c) fat content, (d) salt content, (e) pH, (f) water activity, (g) hardness, and (h) change in color of cheese coated with antimicrobial edible coatings: solution 1 ( $\mathbf{\Lambda}, 6 \mathrm{~g} / \mathrm{L}$ lactic acid and $0.25 \mathrm{~g} / \mathrm{L}$ natamycin), solution 2 (ө, $20 \mathrm{~g} / \mathrm{L}$ chitooligosaccharides (COS) and $0.25 \mathrm{~g} / \mathrm{L}$ natamycin], or solution 3 (ם, $6 \mathrm{~g} / \mathrm{L}$ lactic acid, $20 \mathrm{~g} / \mathrm{L} \mathrm{COS}$, and $0.25 \mathrm{~g} / \mathrm{L}$ natamycin), compared with cheese coated with commercial coating $(\square)$ and uncoated cheese $(\mathrm{O})$, throughout $60 \mathrm{~d}$ of storage at $10^{\circ} \mathrm{C}$ and $85 \%$ relative humidity.

recorded for uncoated cheese, whereas significant $(P$ $>0.05)$ differences were not observed between cheeses bearing different coatings.
The values of moisture loss obtained here were lower than those reported by Cerqueira et al. (2009) using a galactomannan edible coating evaluated after $21 \mathrm{~d}$. 
Moisture loss in our study averaged 13.6, 13.8, and $22.0 \%$ for cheese coated with antimicrobial edible coatings, commercial coated cheese, and uncoated cheese, respectively, whereas that in Cerqueira et al. (2009) ranged between 19.6 and $23.4 \%$ for coated and uncoated cheeses, respectively. Antimicrobial edible coatings decreased the weight and moisture loss of cheese by an average of 9.1 and $8.6 \%$ (wt/wt), respectively, whereas the commercial coating decreased weight and moisture by 8.8 and $8.2 \%$ (wt/wt), respectively. The uncoated cheese exhibited losses in weight and moisture of approximately 33 and $27 \%$ (wt/wt), respectively, by the end of storage. This observation suggests that antimicrobial edible coatings were able to slow water loss of cheese similarly to standard commercial coatings, probably because of their similar water vapor permeabilities.

The presence of coating did not significantly $(P>$ 0.05 ) affect fat and salt contents (Figure 2c and d). Moreover, the antimicrobial edible coating solutions exhibited performance with regard to fat and salt contents similar to that of the commercial coating; statistically significant differences $(P>0.05)$ were not observed between cheeses with either type of coating. The contents of fat and salt measured at the beginning of storage $(0 \mathrm{~d})$ remained virtually unchanged in all cheeses throughout the storage period.

The variation in $\mathrm{pH}$ as storage time elapsed is depicted in Figure 2e; $\mathrm{pH}$ decreased for all samples, although statistically significant differences $(P>0.05)$ were not observed between coated and uncoated cheeses. Such a $\mathrm{pH}$ decrease may be due to the activity of indigenous lactic acid bacteria that metabolize lactose to lactate, thus leading to acid production (Fathollahi et al., 2010).

Water activity is known to be the main factor affecting stability in semihard cheeses, and we observed high $\mathrm{a}_{\mathrm{w}}$ values $(\sim 0.98)$; this type of cheese generally exhibits $\mathrm{a}_{\mathrm{w}}$ values close to unity (Pantaleão et al., 2007). During storage, $a_{w}$ was not constant; it decreased for coated and uncoated cheeses until the surface reached equilibrium with the surrounding atmosphere. The decrease was statistically higher $(P<0.05)$ over $20 \mathrm{~d}$ of storage and was chiefly affected by water loss (Cerqueira et al., 2009). In addition, degradation of proteins during ripening may have contributed to the decrease in $\mathrm{a}_{\mathrm{w}}$ by releasing carboxyl and amino groups through water binding (Sousa et al., 2001). As observed for weight loss and moisture contents, presence of a coating significantly $(P<0.05)$ reduced $\mathrm{a}_{\mathrm{w}}$ compared with uncoated cheese. Statistically significant differences were not observed between cheeses with different coatings (Figure $2 \mathrm{f})$.

The hardness values for cheese samples throughout storage are shown in Figure 2g. Coated cheeses had lower hardness values and statistically significant $(P<$ $0.05)$ differences were observed between uncoated and coated cheeses. However, significant differences were not found between cheeses bearing either coating type. Moreover, a significant increase $(P<0.05)$ was obtained over $20 \mathrm{~d}$ of storage, corresponding to the period during which the greatest loss of water was observed. The hardness values measured were lower than those reported by Cerqueira et al. (2009) at the same time of storage; this was most probably a result of the lower water loss measured in our cheese samples.

Color analysis, based on color difference $(\Delta E)$, showed that all cheeses changed color throughout storage, and statistically significant $(P<0.05)$ differences were recorded (Figure 2h). Uncoated cheese exhibited the highest values of $\Delta E(P<0.05)$; the differences compared with coated cheeses were increasingly relevant $(P<0.05)$ during the first $20 \mathrm{~d}$ but stable throughout the remainder of the storage period. The observed change in color can be, at least in part, attributed to cheese oxidation, which is lower in cheeses with a coating, because of protection from oxygen (due to lower oxygen permeability) and light (due to coating opacity; Cerqueira et al., 2009). Color change may also be associated with the rate of cheese dehydration, which was lower in coated cheese, thus producing a less dry, and thus less dark, cheese rind.

Cheese coated with the edible antimicrobial coating solutions showed significantly $(P<0.05)$ lower values of $\Delta E$ compared with their commercial counterparts. Moreover, statistically significant $(P<0.05)$ differences were achieved among edible antimicrobial coating solutions. Cheese coated with the edible coating incorporating COS showed the lowest $(P<0.05) \Delta E$ values, likely because of the yellow-brownish color exhibited by those coatings at the beginning of storage; this cheese was therefore less susceptible to light oxidation. The statistically $(P<0.05)$ lower $\Delta E$ values observed for the edible coating incorporating $6 \mathrm{~g} / \mathrm{L}$ lactic acid, 20 $\mathrm{g} / \mathrm{L}$ COS, and $0.25 \mathrm{~g} / \mathrm{L}$ natamycin compared with the coating with $20 \mathrm{~g} / \mathrm{L} \mathrm{COS}$ and $0.25 \mathrm{~g} / \mathrm{L}$ natamycin, or for the edible coating containing $6 \mathrm{~g} / \mathrm{L}$ lactic acid and $0.25 \mathrm{~g} / \mathrm{L}$ natamycin compared with commercial coating, may be attributed to presence of lactic acid, because of its acidulant power that may constrain color changes (Cagri et al., 2004).

\section{Microbiological Profile}

Microbiological analysis of cheeses (Table 1) showed no detectable growth of pathogenic or contaminant $(<100 \mathrm{cfu} / \mathrm{g})$ microorganisms at $0 \mathrm{~d}$ of storage. On the other hand, lactic acid and total mesophilic aerobic bacteria (that reflects lactic acid bacteria counts) 
ranged between 6 and $8 \log (\mathrm{cfu} / \mathrm{g})$. These results are in agreement with data pertaining to Turkish white cheeses or Mozzarella (Öner et al., 2006; Duan et al., 2007).

The counts of Lactococcus spp., Lactobacillus spp., and total mesophiles were high for all cheeses (Table 1), confirming the presence of a (controlled) starter culture in cheese that was able to grow on plate count agar and thus contribute to the total mesophilic counts. Moreover, a significant $(P<0.05)$ increase in the number of the aforementioned microorganisms occurred at the early stages of ripening (i.e., the first 20 $\mathrm{d}$ of storage), and a slight, albeit not significant $(P>$ 0.05 ), decrease at later stages was observed as well. Similar results were reported by Manolopoulou et al. (2003) for Feta cheese. These results imply that our edible antimicrobial coatings did not inhibit the starter microflora, which remained at high levels throughout storage.

Moreover, counts of Lactococcus spp. and Lactobacillus spp. were significantly $(P<0.05)$ higher (by $\sim 1$ log cycle) for coated cheese than for its uncoated counterparts (Table 1). Hence, the presence of coating favors growth or survival of those bacteria, presumably by reducing permeability to oxygen and increasing $a_{w}$, factors that otherwise would limit their growth in uncoated cheese. However, statistically significant differences were not recorded among cheeses bearing different coatings, which may indicate that edible coatings with antimicrobial compounds (unlike the commercial coating with only natamycin) do not disturb the natural microbial balance in cheese.

Significantly higher $(P<0.05)$ counts of total mesophilic aerobic bacteria were obtained for uncoated

Table 1. Viable cell counts $[\log (\mathrm{cfu} / \mathrm{g})$, means $\pm \mathrm{SD}]$ of cheese coated with edible antimicrobial coatings compared with cheese coated with commercial coating and uncoated cheese throughout $60 \mathrm{~d}$ of storage at $10^{\circ} \mathrm{C}$ and $85 \%$ relative humidity

Storage time $(d)$

\begin{tabular}{|c|c|c|c|c|c|c|}
\hline Microorganism & Coating $^{1}$ & 0 & 10 & 20 & 40 & 60 \\
\hline \multirow[t]{5}{*}{ Lactococcus spp. } & Solution 1 & $7.23 \pm 0.22^{\mathrm{a}, \mathrm{A}}$ & $8.46 \pm 0.44^{\mathrm{b}, \mathrm{A}}$ & $8.77 \pm 0.32^{\mathrm{b}, \mathrm{A}}$ & $8.43 \pm 0.38^{\mathrm{b}, \mathrm{A}}$ & $8.22 \pm 0.43^{\mathrm{b}, \mathrm{A}}$ \\
\hline & Solution 2 & $7.36 \pm 0.38^{\mathrm{a}, \mathrm{A}}$ & $8.54 \pm 0.36^{\mathrm{b}, \mathrm{A}}$ & $8.89 \pm 0.46^{\mathrm{b}, \mathrm{A}}$ & $8.63 \pm 0.33^{\mathrm{b}, \mathrm{A}}$ & $8.35 \pm 0.35^{\mathrm{b}, \mathrm{A}}$ \\
\hline & Solution 3 & $7.29 \pm 0.43^{\mathrm{a}, \mathrm{A}}$ & $8.32 \pm 0.44^{\mathrm{b}, \mathrm{A}}$ & $8.60 \pm 0.35^{\mathrm{b}, \mathrm{A}}$ & $8.33 \pm 0.23^{\mathrm{b}, \mathrm{A}}$ & $8.19 \pm 0.35^{\mathrm{b}, \mathrm{A}}$ \\
\hline & Commercial & $7.24 \pm 0.20^{\mathrm{a}, \mathrm{A}}$ & $8.33 \pm 0.29^{\mathrm{b}, \mathrm{A}}$ & $8.71 \pm 0.35^{\mathrm{b}, \mathrm{A}}$ & $8.50 \pm 0.35^{\mathrm{b}, \mathrm{A}}$ & $8.37 \pm 0.41^{\mathrm{b}, \mathrm{A}}$ \\
\hline & None & $7.33 \pm 0.28^{\mathrm{a}, \mathrm{A}}$ & $7.51 \pm 0.19^{\mathrm{a}, \mathrm{B}}$ & $7.79 \pm 0.35^{\mathrm{a}, \mathrm{C}}$ & $7.58 \pm 0.20^{\mathrm{a}, \mathrm{B}}$ & $7.41 \pm 0.22^{\mathrm{a}, \mathrm{B}}$ \\
\hline \multirow[t]{5}{*}{ Lactobacillus spp. } & Solution 1 & $6.80 \pm 0.33^{\mathrm{a}, \mathrm{A}}$ & $7.43 \pm 0.34^{\mathrm{b}, \mathrm{A}}$ & $7.92 \pm 0.37^{\mathrm{b}, \mathrm{A}}$ & $7.55 \pm 0.35^{\mathrm{b}, \mathrm{A}}$ & $7.32 \pm 0.43^{\mathrm{b}, \mathrm{A}}$ \\
\hline & Solution 2 & $6.63 \pm 0.38^{\mathrm{a}, \mathrm{A}}$ & $7.68 \pm 0.30^{\mathrm{b}, \mathrm{A}}$ & $8.16 \pm 0.46^{\mathrm{b}, \mathrm{A}}$ & $7.75 \pm 0.33^{\mathrm{b}, \mathrm{A}}$ & $7.52 \pm 0.35^{\mathrm{b}, \mathrm{A}}$ \\
\hline & Solution 3 & $6.74 \pm 0.43^{\mathrm{a}, \mathrm{A}}$ & $7.50 \pm 0.45^{\mathrm{b}, \mathrm{A}}$ & $8.09 \pm 0.23^{\mathrm{b}, \mathrm{A}}$ & $7.63 \pm 0.41^{\mathrm{b}, \mathrm{A}}$ & $7.68 \pm 0.31^{\mathrm{b}, \mathrm{A}}$ \\
\hline & Commercial & $6.71 \pm 0.20^{\mathrm{a}, \mathrm{A}}$ & $7.71 \pm 0.20^{\mathrm{b}, \mathrm{A}}$ & $8.13 \pm 0.41^{\mathrm{b}, \mathrm{A}}$ & $7.59 \pm 0.38^{\mathrm{b}, \mathrm{A}}$ & $7.35 \pm 0.50^{\mathrm{b}, \mathrm{A}}$ \\
\hline & None & $6.49 \pm 0.15^{\mathrm{a}, \mathrm{A}}$ & $6.81 \pm 0.20^{\mathrm{b}, \mathrm{B}}$ & $7.29 \pm 0.31^{\mathrm{b}, \mathrm{B}}$ & $6.89 \pm 0.11^{\mathrm{b}, \mathrm{B}}$ & $6.53 \pm 0.10^{\mathrm{a}, \mathrm{B}}$ \\
\hline \multirow[t]{5}{*}{ Mesophiles } & Solution 1 & $6.53 \pm 0.22^{\mathrm{a}, \mathrm{A}}$ & $7.41 \pm 0.33^{\mathrm{b}, \mathrm{A}}$ & $7.85 \pm 0.41^{\mathrm{b}, \mathrm{A}}$ & $7.53 \pm 0.28^{\mathrm{b}, \mathrm{A}}$ & $7.35 \pm 0.27^{\mathrm{b}, \mathrm{A}}$ \\
\hline & Solution 2 & $6.46 \pm 0.18^{\mathrm{a}, \mathrm{A}}$ & $7.33 \pm 0.43^{\mathrm{b}, \mathrm{A}}$ & $7.97 \pm 0.36^{\mathrm{b}, \mathrm{A}}$ & $7.48 \pm 0.20^{\mathrm{b}, \mathrm{A}}$ & $7.26 \pm 0.41^{\mathrm{b}, \mathrm{A}}$ \\
\hline & Solution 3 & $6.50 \pm 0.23^{\mathrm{a}, \mathrm{A}}$ & $7.39 \pm 0.41^{\mathrm{b}, \mathrm{A}}$ & $8.06 \pm 0.32^{\mathrm{b}, \mathrm{A}}$ & $7.65 \pm 0.34^{\mathrm{b}, \mathrm{A}}$ & $7.41 \pm 0.38^{\mathrm{b}, \mathrm{A}}$ \\
\hline & Commercial & $6.37 \pm 0.19^{\mathrm{a}, \mathrm{A}}$ & $7.21 \pm 0.30^{\mathrm{b}, \mathrm{A}}$ & $7.79 \pm 0.39^{\mathrm{b}, \mathrm{A}}$ & $7.42 \pm 0.19^{\mathrm{b}, \mathrm{A}}$ & $6.21 \pm 0.26^{\mathrm{b}, \mathrm{A}}$ \\
\hline & None & $6.40 \pm 0.20^{\mathrm{a}, \mathrm{A}}$ & $8.31 \pm 0.29^{\mathrm{b}, \mathrm{B}}$ & $8.90 \pm 0.40^{\mathrm{b}, \mathrm{B}}$ & $8.51 \pm 0.40^{\mathrm{b}, \mathrm{B}}$ & $8.20 \pm 0.32^{\mathrm{b}, \mathrm{B}}$ \\
\hline \multirow[t]{5}{*}{ Staphylococcus spp. } & Solution 1 & $<2.00^{\mathrm{a}, \mathrm{A}}$ & $<2.00^{\mathrm{a}, \mathrm{A}}$ & $<2.00^{\mathrm{a}, \mathrm{A}}$ & $<2.00^{\mathrm{a}, \mathrm{A}}$ & $<2.00^{\mathrm{a}, \mathrm{A}}$ \\
\hline & Solution 2 & $<2.00^{\mathrm{a}, \mathrm{A}}$ & $<2.00^{\mathrm{a}, \mathrm{A}}$ & $<2.00^{\mathrm{a}, \mathrm{A}}$ & $<2.00^{\mathrm{a}, \mathrm{A}}$ & $<2.00^{\mathrm{a}, \mathrm{A}}$ \\
\hline & Solution 3 & $<2.00^{\mathrm{a}, \mathrm{A}}$ & $<2.00^{\mathrm{a}, \mathrm{A}}$ & $<2.00^{\mathrm{a}, \mathrm{A}}$ & $<2.00^{\mathrm{a}, \mathrm{A}}$ & $<2.00^{\mathrm{a}, \mathrm{A}}$ \\
\hline & Commercial & $<2.00^{\mathrm{a}, \mathrm{A}}$ & $<2.00^{\mathrm{a}, \mathrm{A}}$ & $2.50 \pm 0.29^{\mathrm{a}, \mathrm{B}}$ & $3.33 \pm 0.31^{\mathrm{b}, \mathrm{B}}$ & $4.22 \pm 0.43^{\mathrm{c}, \mathrm{B}}$ \\
\hline & None & $<2.00^{\mathrm{a}, \mathrm{A}}$ & $2.82 \pm 0.31^{\mathrm{b}, \mathrm{B}}$ & $3.97 \pm 0.43^{\mathrm{c}, \mathrm{C}}$ & $4.82 \pm 0.28^{\mathrm{d}, \mathrm{C}}$ & $6.02 \pm 0.51^{\mathrm{e}, \mathrm{C}}$ \\
\hline \multirow[t]{5}{*}{ Pseudomonas spp. } & Solution 1 & $<2.00^{\mathrm{a}, \mathrm{A}}$ & $<2.00^{\mathrm{a}, \mathrm{A}}$ & $<2.00^{\mathrm{a}, \mathrm{A}}$ & $<2.00^{\mathrm{a}, \mathrm{A}}$ & $<2.00^{\mathrm{a}, \mathrm{A}}$ \\
\hline & Solution 2 & $<2.00^{\mathrm{a}, \mathrm{A}}$ & $<2.00^{\mathrm{a}, \mathrm{A}}$ & $<2.00^{\mathrm{a}, \mathrm{A}}$ & $<2.00^{\mathrm{a}, \mathrm{A}}$ & $<2.00^{\mathrm{a}, \mathrm{A}}$ \\
\hline & Solution 3 & $<2.00^{\mathrm{a}, \mathrm{A}}$ & $<2.00^{\mathrm{a}, \mathrm{A}}$ & $<2.00^{\mathrm{a}, \mathrm{A}}$ & $<2.00^{\mathrm{a}, \mathrm{A}}$ & $<2.00^{\mathrm{a}, \mathrm{A}}$ \\
\hline & Commercial & $<2.00^{\mathrm{a}, \mathrm{A}}$ & $<2.00^{\mathrm{a}, \mathrm{A}}$ & $<2.00^{\mathrm{a}, \mathrm{A}}$ & $<2.00^{\mathrm{a}, \mathrm{aA}}$ & $2.12 \pm 0.32^{\mathrm{b}, \mathrm{B}}$ \\
\hline & None & $<2.00^{\mathrm{a}, \mathrm{A}}$ & $<2.00^{\mathrm{a}, \mathrm{A}}$ & $2.32 \pm 0.12^{\mathrm{b}, \mathrm{B}}$ & $2.95 \pm 0.33^{\mathrm{c}, \mathrm{B}}$ & $3.72 \pm 0.21^{\mathrm{d}, \mathrm{C}}$ \\
\hline \multirow[t]{5}{*}{ Enterobacteriaceae } & Solution 1 & $<2.00^{\mathrm{a}, \mathrm{A}}$ & $<2.00^{\mathrm{a}, \mathrm{A}}$ & $<2.00^{\mathrm{a}, \mathrm{A}}$ & $<2.00^{\mathrm{a}, \mathrm{A}}$ & $<2.00^{\mathrm{a}, \mathrm{A}}$ \\
\hline & Solution 2 & $<2.00^{\mathrm{a}, \mathrm{A}}$ & $<2.00^{\mathrm{a}, \mathrm{A}}$ & $<2.00^{\mathrm{a}, \mathrm{A}}$ & $<2.00^{\mathrm{a}, \mathrm{A}}$ & $<2.00^{\mathrm{a}, \mathrm{A}}$ \\
\hline & Solution 3 & $<2.00^{\mathrm{a}, \mathrm{A}}$ & $<2.00^{\mathrm{a}, \mathrm{A}}$ & $<2.00^{\mathrm{a}, \mathrm{A}}$ & $<2.00^{\mathrm{a}, \mathrm{A}}$ & $<2.00^{\mathrm{a}, \mathrm{A}}$ \\
\hline & Commercial & $<2.00^{\mathrm{a}, \mathrm{A}}$ & $<2.00^{\mathrm{a}, \mathrm{A}}$ & $2.87 \pm 0.35^{\mathrm{b}, \mathrm{B}}$ & $3.61 \pm 0.40^{\mathrm{c}, \mathrm{B}}$ & $4.42 \pm 0.21^{\mathrm{d}, \mathrm{B}}$ \\
\hline & None & $<2.00^{\mathrm{a}, \mathrm{A}}$ & $2.25 \pm 0.21^{\mathrm{b}, \mathrm{B}}$ & $3.75 \pm 0.33^{\mathrm{c}, \mathrm{C}}$ & $4.82 \pm 0.21^{\mathrm{d}, \mathrm{C}}$ & $6.12 \pm 0.41^{\mathrm{e}, \mathrm{C}}$ \\
\hline \multirow[t]{5}{*}{ Yeasts and molds } & Solution 1 & $<2.00^{\mathrm{a}, \mathrm{A}}$ & $<2.00^{\mathrm{a}, \mathrm{A}}$ & $<2.00^{\mathrm{a}, \mathrm{A}}$ & $<2.00^{\mathrm{a}, \mathrm{A}}$ & $<2.00^{\mathrm{a}, \mathrm{A}}$ \\
\hline & Solution 2 & $<2.00^{\mathrm{a}, \mathrm{A}}$ & $<2.00^{\mathrm{a}, \mathrm{A}}$ & $<2.00^{\mathrm{a}, \mathrm{A}}$ & $<2.00^{\mathrm{a}, \mathrm{A}}$ & $<2.00^{\mathrm{a}, \mathrm{A}}$ \\
\hline & Solution 3 & $<2.00^{\mathrm{a}, \mathrm{A}}$ & $<2.00^{\mathrm{a}, \mathrm{A}}$ & $<2.00^{\mathrm{a}, \mathrm{A}}$ & $<2.00^{\mathrm{a}, \mathrm{A}}$ & $<2.00^{\mathrm{a}, \mathrm{A}}$ \\
\hline & Commercial & $<2.00^{\mathrm{a}, \mathrm{A}}$ & $<2.00^{\mathrm{a}, \mathrm{A}}$ & $<2.00^{\mathrm{a}, \mathrm{A}}$ & $<2.00^{\mathrm{a}, \mathrm{A}}$ & $<2.00^{\mathrm{a}, \mathrm{A}}$ \\
\hline & None & $<2.00^{\mathrm{a}, \mathrm{A}}$ & $3.82 \pm 0.24^{\mathrm{b}, \mathrm{B}}$ & $4.65 \pm 0.43^{\mathrm{c}, \mathrm{B}}$ & $5.72 \pm 0.33^{\mathrm{d}, \mathrm{B}}$ & $6.62 \pm 0.53^{\mathrm{e}, \mathrm{B}}$ \\
\hline
\end{tabular}

$\overline{{ }^{a}-\mathrm{e}, \mathrm{A}-\mathrm{C}}$ Means within the same row (lowercase letters) and column (uppercase letters), for each microorganism, with the same letter, do not statistically differ from each other $(P>0.05)$.

${ }^{1}$ Solution 1: $6 \mathrm{~g} / \mathrm{L}$ lactic acid and $0.25 \mathrm{~g} / \mathrm{L}$ natamycin; solution 2: $20 \mathrm{~g} / \mathrm{L}$ chitooligosaccharides (COS) and $0.25 \mathrm{~g} / \mathrm{L}$ natamycin; solution 3: $6 \mathrm{~g} / \mathrm{L}$ lactic acid, $20 \mathrm{~g} / \mathrm{L}$ COS, and $0.25 \mathrm{~g} / \mathrm{L}$ natamycin. 
cheese than for coated cheeses (and by $10 \mathrm{~d}$ of storage); this may reflect the greater growth of contaminant bacteria, as confirmed in selective media. Once again, statistically significant $(P>0.05)$ differences were not observed among cheeses with distinct coatings (Table $1)$.

Compared with uncoated cheese, cheese with a commercial coating did not display growth of yeasts and molds, which demonstrates the effectiveness of such a coating against those microorganisms. This result was expected, because the commercial coating included natamycin, a natural antimycotic polyene, with known success in preventing growth of yeasts and molds on cheese surfaces (Amefia et al., 2006). Conversely, the smaller increase in pathogenic and contaminant bacteria counts on cheese coated with commercial coating compared with uncoated cheeses may be accounted for by the protective effect of the coating itself, which reduces gas permeability and decreases oxygen transfer rate into the cheese. Therefore, oxygen becomes less available for growth of aerobic bacteria. At the same time, the commercial coating protects from water loss and, consequently, from a reduction in $\mathrm{a}_{\mathrm{w}}$ that is a critical factor for bacterial growth. Moreover, as the commercial coating included only natamycin, bacterial growth began after $20 \mathrm{~d}$ for Enterobacteriaceae and Staphylococcus spp. and by $60 \mathrm{~d}$ for Pseudomonas spp.

Cheeses coated with the antimicrobial coatings did not show growth $(<100 \mathrm{cfu} / \mathrm{g})$ of Staphylococcus spp., Pseudomonas spp., Enterobacteriaceae, yeasts, or molds (Table 1), confirming the ability of the antimicrobial compounds (i.e., lactic acid and COS) in the edible coating to ensure the safety of cheese for at least $60 \mathrm{~d}$ of storage.

\section{Sensory Profile}

The results of the sensory analysis of cheese samples are presented in Table 2. Sensory assessments were not performed for uncoated cheese after $0 \mathrm{~d}$ of storage because it showed growth $(>100 \mathrm{cfu} / \mathrm{g})$ of yeasts and molds, as well as of other contaminant bacteria (Table 1 ), and thus might be unsafe for sensory evaluation. Cheese coated with the commercial coating showed growth of Staphylococcus spp. and Enterobacteriaceae, 2.50 and $2.87 \log (\mathrm{cfu} / \mathrm{g})$, respectively, over $20 \mathrm{~d}$ of storage; hence, those samples were also considered unsafe for flavor evaluation, and only external sensory attributes were assessed. The frequency of evaluation was chosen to be consistent with the typical storage period of the cheese type studied, and the minimum sampling interval $(10 \mathrm{~d})$ was a compromise between representativeness of changes and number of samples.
By $0 \mathrm{~d}$ of storage, rind color was less intense for uncoated cheese, for cheese coated with solution 1 (i.e., 6 $\mathrm{g} / \mathrm{L}$ lactic acid and $0.25 \mathrm{~g} / \mathrm{L}$ natamycin), and for cheese with commercial coating (Table 2); statistically significant $(P>0.05)$ differences were not perceived among these samples. Throughout storage, color became more intense for all cheeses; however, edible coatings containing solution 1 exhibited the lowest intensity of color by $60 \mathrm{~d}$ of storage, whereas those containing solution 3 (i.e., $6 \mathrm{~g} / \mathrm{L}$ lactic acid, $20 \mathrm{~g} / \mathrm{L} \mathrm{COS}$, and $0.25 \mathrm{~g} / \mathrm{L}$ natamycin) and by solution 2 (i.e., $20 \mathrm{~g} / \mathrm{L} \operatorname{COS}$ and $0.25 \mathrm{~g} / \mathrm{L}$ natamycin) had the lowest increase in color intensity throughout storage. These results are consistent with the $\Delta E$ values referred to above regarding color measurement. Cheese with commercial coating displayed the highest increase in color (2.0 points); this cheese, according to the panelists, became increasingly yellow with storage.

Cheeses coated with edible coatings (all solutions) exhibited the lowest rind odor intensity throughout storage time. Conversely, cheese coated with the commercial coating displayed the most intense odor; statistically significant $(P<0.05)$ differences were obtained among these cheeses. Moreover, the panelists claimed (in the observations section) that cheese with the commercial coating presented an odor similar to that of glue at $0 \mathrm{~d}$ of storage. However, as storage time elapsed, the intensity of this odor decreased significantly $(P<$ 0.05 ), reaching $<1.4$ points at $60 \mathrm{~d}$ (Table 2 ).

In terms of texture, hardness was an important property to differentiate between coated and uncoated cheeses. Uncoated cheeses were significantly softer $(P<$ $0.05)$ than coated cheeses at $0 \mathrm{~d}$ of storage. Statistically significant $(P>0.05)$ differences were not obtained among any of the cheeses with coatings. Throughout storage, hardness increased significantly $(P<0.05)$ for all coated samples (increases ranging from 1.5 to 1.8 points; Table 2). These results are consistent with the response of those cheeses to hardness measurements, which showed an increase accompanying the loss of water during storage.

Cheese coated with edible coating containing solution 1 displayed the lowest $(P<0.05)$ rind flavor intensity among coated cheeses and had similar $(P>0.05)$ flavor intensity to the uncoated cheeses at $0 \mathrm{~d}$ of storage. The rind of cheese coated with commercial coating did not undergo tasting; the flavor of only the cheese mass was assessed at $10 \mathrm{~d}$ of storage. According to the panelists, the bulk of the commercial coating cheeses exhibited high flavor intensity, somewhat similar to gum, indicating that this flavor was transmitted from the rind of cheese coated with commercial coating to the inner mass. Conversely, cheese coated with edible coatings 
Table 2. Sensory differences (means \pm SD), assessed by a group of trained panelists using a 5-point scale, between cheese coated with antimicrobial edible coatings compared with cheese coated with commercial coating and uncoated cheese throughout $60 \mathrm{~d}$ of storage at $10^{\circ} \mathrm{C}$ and $85 \%$ relative humidity

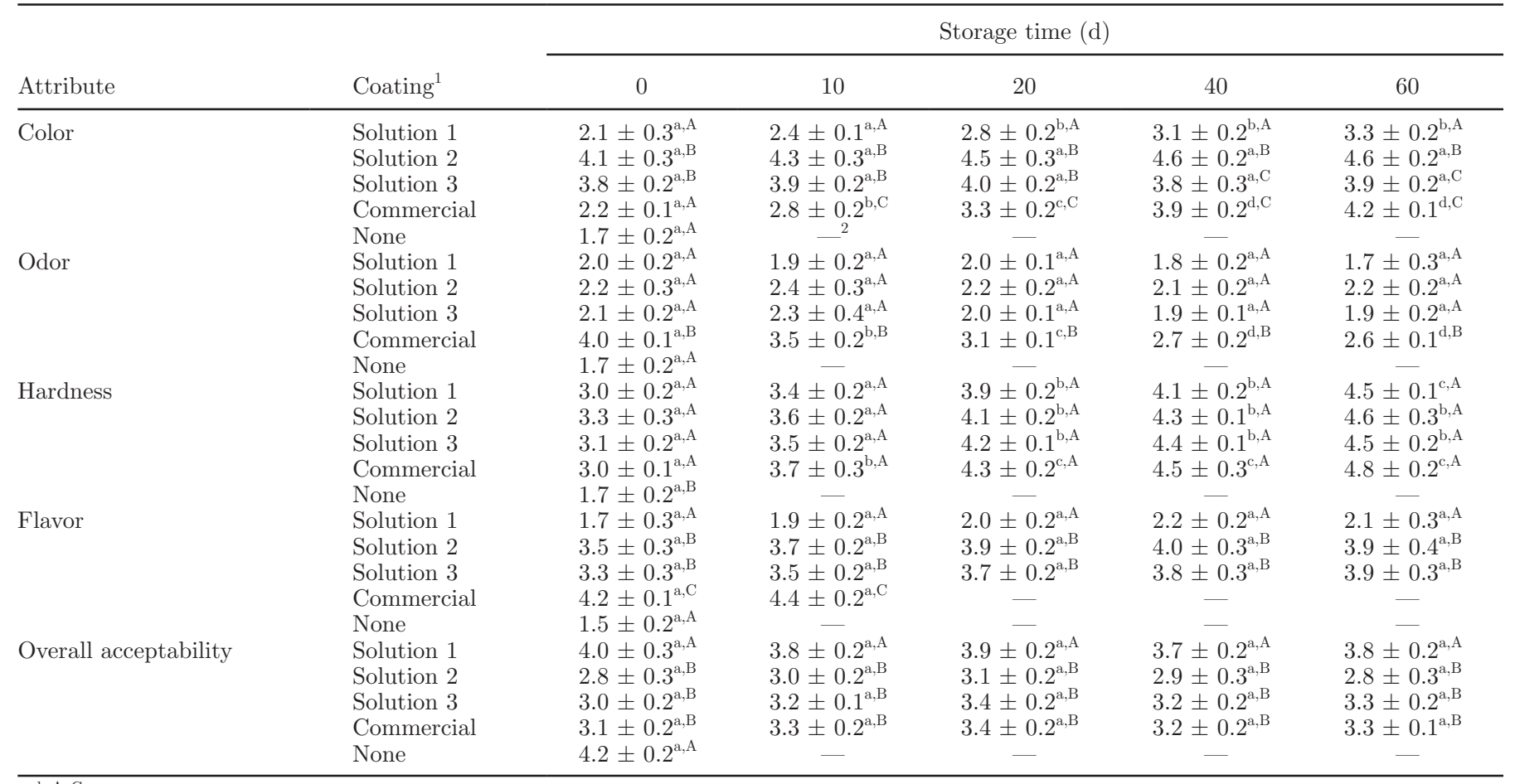

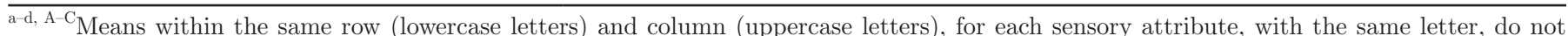
statistically differ from each other $(P>0.05)$.

${ }^{1}$ Solution 1: $6 \mathrm{~g} / \mathrm{L}$ lactic acid and $0.25 \mathrm{~g} / \mathrm{L}$ natamycin; solution 2: $20 \mathrm{~g} / \mathrm{L}$ chitooligosaccharides (COS) and $0.25 \mathrm{~g} / \mathrm{L}$ natamycin; solution 3: 6 g/L lactic acid, $20 \mathrm{~g} / \mathrm{L} \mathrm{COS}$, and $0.25 \mathrm{~g} / \mathrm{L}$ natamycin.

${ }^{2}$ Not determined (for safety reasons).

containing solutions 2 and 3 had similar $(P>0.05)$ flavor intensity during the whole storage period. According to the panelists, cheese coated with these edible coating solutions exhibited a bitter flavor and a high astringency.

Finally, in terms of overall acceptability, cheese coated with edible coating containing solution 1 (i.e., $6 \mathrm{~g} / \mathrm{L}$ lactic acid and $0.25 \mathrm{~g} / \mathrm{L}$ natamycin) had acceptability statistically similar $(P>0.05)$ to that of uncoated cheese at $0 \mathrm{~d}$ of storage, even though most cheese will not be commercially available immediately after manufacture. More importantly, cheese coated with edible coating containing solution 1 was, of the coated cheese samples, the most accepted (highest acceptability score) by the panelists throughout the $60 \mathrm{~d}$ of storage. Cheeses coated with the remaining edible and commercial coatings were considered acceptable by the panelists, showing a similar $(P>0.05)$ acceptability score over storage. A score of "accepted" indicates similarity to regular cheese bearing the standard packaging film.

\section{CONCLUSIONS}

The presence of coating decreased water loss, hardness, and color changes, as well as microbial development, of cheeses throughout storage for up to $60 \mathrm{~d}$. The antimicrobial edible coating solutions tested here were a suitable alternative to commercial coating, because all coated cheeses had similar values in terms of physicochemical properties, except for color analysis, which showed a higher score in the case of antimicrobial edible coating solutions. Coatings incorporating COS exhibited a yellow-brown color, which may constrain applications in certain types of cheese, although COS could be used in manufacture of cheeses with a novel and distinct appearance. In addition, edible antimicrobial coating solutions prevented growth of pathogenic and contaminant microorganisms and did not inhibit lactic acid bacteria for at least $60 \mathrm{~d}$. The commercial coating inhibited growth of yeasts and molds only, while allowing growth of bacteria to some extent. Sensory analyses correlated well with physicochemical measure- 
ments for both surface color and hardness. Overall, the antimicrobial edible coating containing natamycin and lactic acid was selected as the best option for cheese coating.

\section{ACKNOWLEDGMENTS}

Partial funding for this research work was provided by project Cheesecover, administered by Agência de Inovação-POCTI: Programa Operacional de Ciência, Tecnologia e Inovação (Lisbon, Portugal). Funding for author O. L. Ramos was via a postdoctoral fellowship (SFRH/BPD/80766/2011), administered by Fundação para a Ciência e a Tecnologia (Lisbon, Portugal) and supervised by F. X. Malcata.

\section{REFERENCES}

Amefia, A. E., J. M. Abu-Ali, and S. A. Barringer. 2006. Improved functionality of food additives with electrostatic coating. Innov. Food Sci. Emerg. Technol. 7:176-181.

Baird-Parker, A. C. 1969. The use of Baird-Parker's medium for the isolation and enumeration of Staphylococcus aureus. Pages 1-8 in Isolation Methods for Bacteriologists. Soc. Appl. Bacteriol. Technol. Ser. 3. D. A. Shapton, and G. W. Gould, ed. Academic Press, London, UK.

Cagri, A., Z. Ustunol, and E. T. Ryser. 2004. Antimicrobial edible films and coatings. J. Food Prot. 67:833-848.

Campos, C. A., L. N. Gerschenson, and S. K. Flores. 2011. Development of edible films and coatings with antimicrobial activity. Food Bioprocess Technol. 4:849-875.

Cerqueira, M. A., A. M. Lima, B. W. S. Souza, J. A. Teixeira, R. A. Moreira, and A. A. Vicente. 2009. Functional polysaccharides as edible coatings for cheese. J. Agric. Food Chem. 57:1456-1462.

Cerqueira, M. A., M. J. Sousa-Gallagher, I. Macedo, R. RodriguezAguilera, B. W. S. Souza, J. A. Teixeira, and A. A. Vicente. 2010. Use of galactomannan edible coating application and storage temperature for prolonging shelf-life of "Regional" cheese. J. Food Eng. 97:87-94.

de Oliveira, T. M., N. F. S. de Fátima, R. M. Pereira, and K. Fraga. 2007. Development and evaluation of antimicrobial natamycin-incorporated film in Gorgonzola cheese conservation. Packag. Technol. Sci. 20:147-153.

Duan, J., S.-I. Park, M. A. Daeschel, and Y. Zhao. 2007. Antimicrobial chitosan-lysozyme (CL) films and coatings for enhancing microbial safety of Mozzarella cheese. J. Food Sci. 72:M355-362.

Fajardo, P., J. T. Martins, C. Fuciños, L. Pastrana, J. A. Teixeira, and A. A. Vicente. 2010. Evaluation of a chitosan-based edible film as carrier of natamycin to improve the storability of Saloio cheese. J. Food Eng. 101:349-356.

Fathollahi, I., J. Hesari, S. Azadmard, and S. Oustan. 2010. Influence of proteolysis and soluble calcium levels on textural changes in the interior and exterior of Iranian UF white cheese during ripening. World Acad. Sci. Eng. Technol. 66:844-849.

Kampf, N., and A. Nussinovitch. 2000. Hydrocolloid coating of cheeses. Food Hydrocoll. 14:531-537.

Kester, J. J., and O. R. Fennema. 1986. Edible films and coatings: A review. Food Technol. 40:47-59.

Khwaldia, K., C. Perez, S. Banon, S. Desorby, and J. Hardy. 2004. Milk proteins for edible films and coatings. Crit. Rev. Food Sci Nutr. 44:239-251.

Manolopoulou, E., P. Sarantinopoulos, E. Zoidou, A. Aktypis, E. Moschopoulou, I. G. Kandarakis, and E. M. Anifantakis. 2003. Evolution of microbial populations during traditional Feta cheese manufacture and ripening. Int. J. Food Microbiol. 82:153-161.
Meilgaard, M., G. V. Civille, and B. T. Carr. 1999. Sensory Evaluation Techniques. CRC Press, Boca Raton, FL.

Miles, A. A., S. S. Misra, and J. O. Irwin. 1938. The estimation of the bactericidal power of the blood. J. Hyg. (Lond.) 38:732-749.

Mulvihill, D. M., and M. P. Ennis. 2003. Functional milk proteins: Production and utilisation. Pages $1176-1128$ in Advanced Dairy Chemistry. P. F. Fox, and P. L. H. McSweeney, ed. Kluwer, New York, NY.

Ojagh, S. M., M. Rezaei, S. H. Razavi, and S. M. H. Hosseini. 2010. Development and evaluation of a novel biodegradable film made from chitosan and cinnamon essential oil with low affinity toward water. Food Chem. 122:161-166.

Öner, Z., A. G. Karahan, and H. Aloglu. 2006. Changes in the microbiological and chemical characteristics of an artisanal Turkish white cheese during ripening. J. Food Sci. Technol. 39:449-454.

Pantaleão, I., M. M. E. Pintado, and M. F. F. Poças. 2007. Evaluation of two packaging systems for regional cheese. Food Chem. 102:481-487.

Perez-Gago, M. B., and J. M. Krochta. 2002. Formation and properties of whey protein films and coatings. Pages 159-180 in ProteinBased Films and Coatings. A. Gennadios, ed. CRC Press, Boca Raton. FL.

Ponce, A. G., S. I. Roura, C. E. del Valle, and M. R. Moreira. 2008. Antimicrobial and antioxidant activities of edible coatings enriched with natural plant extracts: In vitro and in vivo studies. Postharvest Biol. Technol. 49:294-300.

Ramos, O. L. 2011. Development and characterization of bioactive, edible whey protein films and coatings to improve quality and safety of food products. PhD Thesis. Technological and Engineering Sciences, Institute of Chemical and Biological Technology (ITQB), New University of Lisbon, Lisbon, Portugal.

Ramos, O. L., J. C. Fernandes, S. I. Silva, M. E. Pintado, and F. X. Malcata. 2012a. Edible films and coatings from whey proteins: A review on formulation, and on mechanical and bioactive properties. Crit. Rev. Food Sci. Nutr. 52:533-552.

Ramos, O. L., J. O. Pereira, S. I. Baptista da Silva, M. Amorim, J. C. Fernandes, J. A. Lopes-da-Silva, M. E. Pintado, and F. X. Malcata. 2012b. Effect of composition of commercial whey protein preparations upon gelation at various $\mathrm{pH}$ values. Food Res. Int. 48:681-689. http://dx.doi.org/10.1016/j.foodres.2012.06.004.

Ramos, O. L., I. Reinas, S. I. Silva, J. C. Fernandes, M. A. Cerqueira, R. N. Pereira, A. A. Vicente, M. F. Poças, M. E. Pintado, and F. X. Malcata. 2013. Effect of whey protein purity and glycerol content upon physical properties of edible films manufactured therefrom. Food Hydrocoll. 30:110-122.

Ramos, O. L., A. C. Santos, M. V. Leão, J. O. Pereira, S. I. Silva, J. C. Fernandes, M. I. Franco, M. E. Pintado, and F. X. Malcata. 2012c. Antimicrobial activities of edible coatings prepared from whey protein isolate, and formulated with various antimicrobial agents: In vitro studies. Int. Dairy J. 25:132-141.

Ramos, O. L., S. I. Silva, J. C. Soares, J. C. Fernandes, M. F. Poças, M. E. Pintado, and F. X. Malcata. 2012d. Features and performance of edible films, obtained from whey protein isolate formulated with antimicrobial compounds. Food Res. Int. 45:351-361.

Reps, A., L. Jedrychowski, J. Tomasik, and K. Wisniewska. 2002. Natamycin in ripening cheeses. Pak. J. Nutr. 1:243-247.

Seydim, A. C., and G. Sarikus. 2006. Antimicrobial activity of whey protein based edible films incorporated with oregano, rosemary and garlic essential oils. Food Res. Int. 39:639-644.

Skurtys, O., C. Acevedo, F. Pedreschi, J. Enronoe, F. Osorio, and J. M. Aguilera. 2010. Food hydrocolloid edible films and coatings. Food Sci. Technol. XX:41-80.

Sousa, M. J., Y. Ardö, and P. L. H. McSweeney. 2001. Advances in the study of proteolysis during cheese ripening. Int. Dairy J. $11: 327-345$.

Syrbe, A., P. B. Fernandes, F. Dannenberg, W. Bauer, and H. Klostermeyer. 1995. Whey protein and polysaccharide mixtures: Polymer incompatibility and its applications. Pages 328-339 in Food Colloids and Macromolecules. E. Dickenson, and D. Lorient, ed. Royal Society of Chemistry, Cambridge, UK. 